\title{
A newly detected ablation phenomenon in Dronning Maud Land, Antarctica
}

\author{
Carl Egede Bøggild and Jan-Gunnar Winther
}

From November 1993 to February 1994 members of the Geological Survey of Greenland (GGU) participated in a Nordic research effort in Antarctica. The Nordic Antarctic Research Programme (NARP) involves Norway, Sweden and Finland, which are all Antarctic Treaty Consultative Partners; Denmark as an observer has participated only since 1992 (Thomsen, 1994; Bøggild et al., 1995). The member countries of NARP have traditionally carried out research in Dronning Maud Land. This region of Antarctica has recently gained new research interest, including survey for a joint European deep drilling programme planned for 1995/96. Future Norwegian climate studies on blue ice will therefore be closely related to the joint European deep drilling programme.

Of the two ice sheets in the world, Greenland and Antarctica, only the Greenland ice sheet displays significant surface melting, since the climate in Antarctica is generally too cold for large scale melting. However, different types of melt phenomena have been observed in blue ice fields in Antarctica. GGU was invited to participate in the Norwegian Antarctic Research Expedition 1993/94 in order to study physical melt processes in Dronning Maud Land in an environment which is similar to near equilibrium areas in the high Arctic regions of the Greenland ice sheet. Only sparse information on such areas exists from the Greenland ice sheet.

To the best of our knowledge the first recorded subsurface melt phenomenon within clear blue ice was discovered during the 1993/94 expedition; numerical modelling shows this to be a consequence of solar radiation penetration and absorption, i.e. the 'solid-state greenhouse effect'. This discovery may contribute to the understanding of runoff from high polar regions of both the Antarctic and Greenland ice sheets.

\section{The Jutulgryta blue ice area}

Occurrences of blue ice in Jutulgryta, Dronning Maud Land, are primarly restricted to isolated areas which are intersected by snow fields (Fig. 1). They are often related to convex surface shapes where exposure to wind is most prominent (Takahashi et al., 1988). The surface topography undulates along the gentle north-westerly slope that leads down to the Jutulgryta depression, and blue ice fields are common and constitute about $70 \%$ of the slope region. The present studies were restricted to an area about $3 \mathrm{~km}$ in radius at an altitude of approximately $140 \mathrm{~m}$ a.s.l. (Fig. 1).

\section{Sub-surface melting}

Since average air temperatures in Antarctica are well below freezing point, past observations of melting have been reported only in nunatak areas where blue ice is in contact with bedrock, rocks in the ice, or with other material which increases heat absorption (Autenboer, 1962; Paige, 1968). However, the sub-surface melting observed in the Jutulgryta depression cannot be explained by these processes in as much as local climatic conditions related to nunataks can be discounted; the nearest nunatak is more than $50 \mathrm{~km}$ away. Moreover, no impurities were found which could lead to internal melting (Bøggild et al., 1995).

Brandt \& Warren (1993) summarise studies of snow temperatures with special emphasis on the occurrence of a maximum temperature below the surface (the "solid-state greenhouse effect') that results from solar radiation penetration and absorption inside the snow, and the fact that long-wave radiative cooling is restricted to the surface. Factors such as radiative heating of sensors, dirt inside ice or a dark layer beneath the snow are reasons for the past reportings of this 'solid state greenhouse effect' in snow (Brandt \& Warren, 1993). Although the idea of a 'solid state greenhouse effect' is attractive, and has been described theoretically by several authors (e.g. Schlatter, 1972; Brandt \& Warren, 1993), Brandt \& Warren state that it is rather questionable within snow, but may in theory occur within blue ice due to the lower extinction coefficient and albedo values compared to those for snow.

The studies in the Jutulgryta area show that observed melting is confined to a zone between 0.5 and $1 \mathrm{~m}$ depth below the blue ice surface, and that this melt layer was consistent throughout the one month of observations (Bøggild et al., 1995). Measurements of sub-surface temperatures in exposed as well as snow-covered blue ice, clearly documents that a melting zone is only present below the surface where blue ice is exposed. Ice temperatures are 

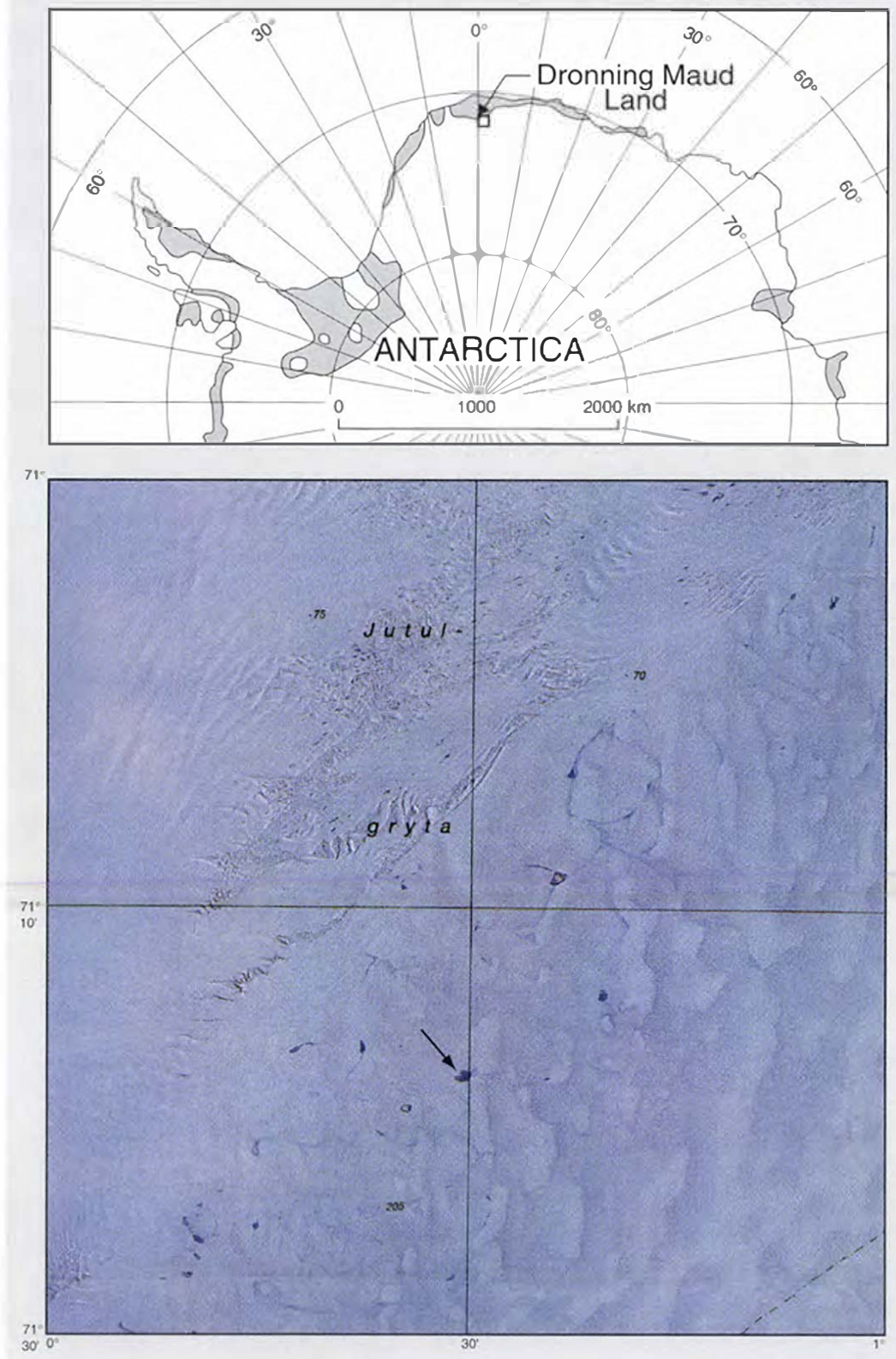

Fig. I. Parl of a satellite enhanced map covering the blue ice region in Jutulgryta. The dark areas are bluc ice fields which are intersected by bright snow fields. The darkest spots are lakes. The location of the camp was $71^{\circ} 23^{\prime} 55^{\prime \prime} \mathrm{S},()^{\circ} 29^{\prime} 55^{\prime \prime} \mathrm{E}$. altitude 14()$_{\mathrm{m}} \mathrm{m}$ a.s.I. indicated with an arrow. gencrally $6^{\circ} \mathrm{C}$ higher than temperatures in snow covered profiles (Fig. 2).

\section{Modelling experiments}

A number of numerical modelling experiments have been carried out in order to reconstruct the sub-surface melt phenomenon and, when positive, sensitivity experiments have been performed to find the parameters which control the formation of a sub-surface melt layer.

The sensitivity studies mainly rely on input parameters and data measured in Jutulgryta during the 1993/94 expedition. When not available, they were obtained from published observations closely matching the Jutul gryta conditions. The theory and numerical scheme behind this non-stationary, combined radiative and thermodynamic model is described in detail by Boggild $(1999(), 1991)$ and Boggeild el al. (1995).

Numerical modelling shows development of a subsurface meltayer (a ()$^{\circ} \mathrm{C}$ zone) in blue ice after only live days of ice exposure (Fig. 3). The solid black line refers to a situation where the snow cover has remained and would 


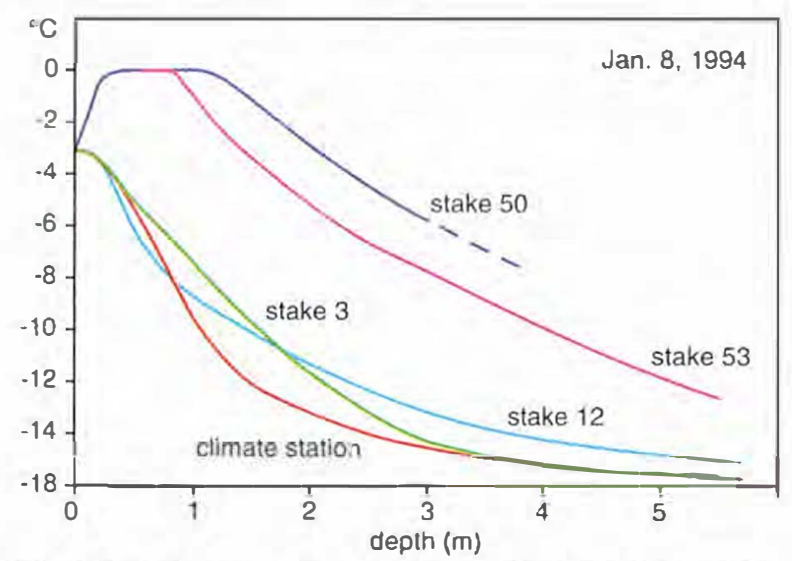

Fig. 2. Suh-surface temperallures recorded on 8 Janually. 1994. Measurements from stake 5() and 53 are from exposed blue ice. Stake 3.12 and the climate station atre from similar. but snow covered profiles.

disable radiative penetration. The maximum just below surface stems entirely from diumal fluctuations of surfice cemperatures. The formation of a melt layer is strongly controlled by penetration and absorption of radiation. which in turn is governed by the surface reflectance (albedo) $\alpha$. the transmittance $\beta$ and the extinction coefficient K(Fig. 3).

The development of steady state temperattures helow the melt layer takes longer to establish with increasing distance from the surface. To simulate temperature evolution over periods of several years it hals been necessary to mod-

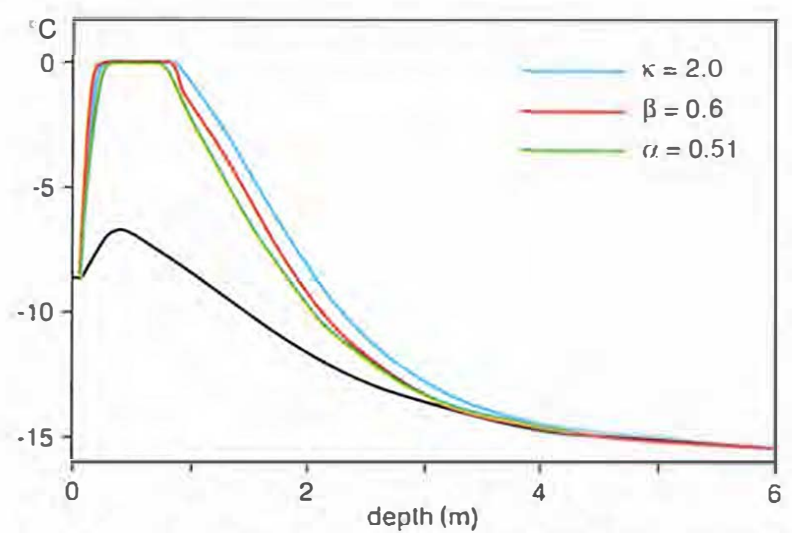

Fig. 3. Simulated temperature profiles based on 5 day runs. $\alpha$ is surface reflectance, $\beta$ is radiation transmiltance and $\alpha$ is extinction coeflicient. From the ligure it appeats that all the three parameters $x, \beta$ and $x$ can independently cause the formation of a sub-surfice meltliyer. The adjustment of $\alpha$ is bised on own observations, whereas $k$ and $\beta$ are adjusted within observed limits suggested by Girenfell \& Maykut (1977). The three curves show that a sub-surfice mellayer can develop by adjusting one parameter within natural limits and keeping the others constant. A detailed discussion of parameters is found in Boggild ef al. (1995). ify the existing model by coarsening the grid resolution to ().5 m (to overeme the demand for computer time). Figure 4 shows how temperatures develop within blue ice after simulation runs of $1,2.4$ and 8 years duration, respectively. The snow profile temperatures from state 3 (Fig. 2) have heen used as initial conditions, although with thermal and optical properties as for bluc ice. Air temperatures and glohal radiation are monthly mean values over 10 years measured at the (ierman Georg von Neumayer ( GivN) station (Helmes. 1989). From 927 air temperature time series. Fortuin (1992) concludes that air temperattures in Antarctical are only significantly dependent on elevation and latitude. The GivN research station is located at approximately the same elevation and latitude as the Jutulgryta area, but some $250 \mathrm{~km}$ to the west. The annual cycle of air temperatures in Jutulgryta call therefore he assumed to be similar to observations from GivN. omitting the need for the complex transfer function necessary in Cireenland when extrapolating a temperature signal over a similar distance (Boggild or al., 1994).

The simulations in Fig. 4 illustrate that several years of exposed blue ice are needed to produce the parallel rise of ice temperatures from the 'cold' snow covered prolile to the 'warm' ice temperatures of exposed blue ice (Fig. 2). The trend is clear, but interpretation camnot be carried further due co lack of observations from winter-time. fl can be stated, however, that sub-surtace melting in blue ice must have occurred over many years in order to raise the temperature by $6^{\circ} \mathrm{C}$ in blue ice, and it probably occurs every austral summer.

\section{Summary and outlook}

The existence of a persistant sub-surfiace melt layer during the melt seasson means that runoff is not restricted to occasional events each year when air temperatures are near or above the melting point. Contributions to seal level rise are quite likely to come from futulgryta and similar areas. because the grounding line of the adjacent ice-shelf is highly crevalssed with hydraulic contact to the seal watter below the ice shelf. It should be noted. however, that the contribution trom this melt phenomenon is rather small in relation to the total annual mass balance turnover of Antarclicia.

The 'invisible' nature of the sub-surfice melting and runofi phenomena are generally confined to at narrow range of summer mean air temperatures. An increalse of air temperature will result in 'classical' surtace melting. whereass a cooling will strongly reduce the formation of a sub-surfice melt layer. Thus, the contined air temperature range under which sub-surface melting can occur makes this phenomenon a good potential indicator for detecting possible future climate changes. 


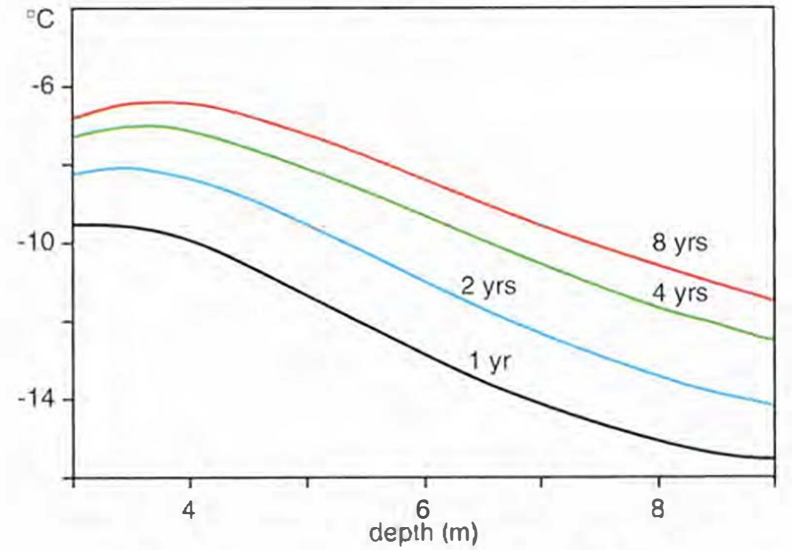

Fig. 4. Evolved temperature profiles after 1. 2. 4 and 8 years of simulations.

The effect of the reported ozone hole over Antarctica on sub-surface melting is not yet known. It is likely that increased penetration of ultraviolet (UV) radiation through the atmosphere will also enhance radiative absorption in bluc ice. since the ice is most transparent to solar radiation penetration in the shortwave UV range and becomes more opaque with increasing wavelength (Grentell \& Maykut, 1977). Once the sub-surface meltlayer is established, it is likely 10 remain due 10 radiative scatter at interfaces inside the ice. New efforts should therefore be devoted to analysing the effect of the ozone hole over Antarctical on the formation of sub-surface melting and runoff. This will be possible by further development of the existing model to include spectral solar radiation and scatter properties.

Our discovery of a widespread "solid-state greenhouse" melt layer in blue ice in Antarctical may also contribute to the understanding ol runofit from the Greenland ice sheet. since similar surface leatures, i.e. frozen lakes and blue ice fields intersected with snow fields, have been documented near the equilibrium line in both East and West Greenland (Echelmeyer el al.,1991: Rech et al.,1991).

Acknowledgements. This is Publication No. 139 of the Norwegian Antarctic Research Expeditions (1993/94). The research programme was funded by the Researcl Council of Norwaly and by the Danish Natural Science Research Council. Travel funding between Norwaly and Denmark provided by Nordisk Forskerutdanningsakademi (NorFa) has greatly stimulated collatoration. Svensk Polarforskningssekretariat is thanked for the excellently organised expedition under the Nordic Antarctic Research Programme 1993/94.

\section{References}

Autenboer. 1: valn 1962: lce mounds and melt phenomena in the Sor-Rondane. Antarctica. I. Ciluciol. 4. 340-354.

Brandt. R. E. \& Warren. S. G. 1993: Solar-leating rates and temperature profiles in Antarctic snow and ice. I. (ilaciol. 39. 99-110.

Boggild, C. E. (9)(): Fin metode til beregning af genfrysning langsen rackke profîler pă Amitsuloog lskappen. Unpublished internal report. Univ. Copenhagen. $5.5 \mathrm{pp}$.

Boggild, C. E. 1991: En smeltende snepakikes masse og energifluxe - helyst ved heregningsmetoder. Linpublislied thesis. Univ. Copenhagen. 94 pp.

Bsggild. C. E.. Reeh, N.. Oerter. H. 1994: Modelling ablation and mass-balance sensitivity to climate change of Storstrommen. North-East Greenland. Global Planet. Change 9. 79) ().

Boggild, C. E, Winther. J.-G.. Sand, K. \& Elvehny, H. 1995: Sub-surface melting in blue ice fields in Dronning Maud Land. Antarctica: observations and modelling. Amm. Cilaciol. 21. 162168.

Echelmeyer, K., Clarke. T. S. \& Harrison. W. I). 1991: Surlicial glaciology of Jakobshaun Isbrax. West Greenland: P'art I. Surfice morphology. .l. Glaciol. 37, 368-382.

Fortuin. J. P. F. 1992: The surface mass balance and temperature of Antarctica. Plt. D. thesis. Liniversity of Ltrecht. The Netherlands. $106 \mathrm{pp}$.

Grenfelt. T. C. \& Maykut, G. A. 1977: The optical properties of ice and snow in the Arctic Bassin. .1. Glaciol. 18. 44.5-46.3.

Helmes. L. 1989: Meteorological dala from Georg von NeumayerStation (Antaltcticil). Berichle aur Polarforsch. 64. 90 pp

Paige, R. A. 1968: Sub-surfice melt pools in the MciMurdo ke Shelf, Antarcticia. I. Cilaciol. 7, 511-516.

Reel, N..Oerter. H. \& Neve, J. K. 199) 1: Supra-glacial lakes on Storstrommen Glacier Northeast Greenland and their relation (o) ice dynamics. Deutche Gesellschalt für Polarforschung. I6. Intemationale Polartagung in Göttingen. I().-13. April 1991. Programme with abstracts.

Schlitter. T. W. 1972: 7he locial surfice energy halance and subsurface temperatture regime in Antarctica. I. Appl. Meterorol. 11. I() $48-1(062$

Takiashashi. S.. Naruse. R., Nakawo. M. \& Male. S. 1988: A hare ice field in east Queen Maud Land, Antarctical, calused by horizontal divergence of drilting snow. Ann. Glaciol. 11, 15616() .

Thomsen, H. H. I994: Glaciological research in Antarctical. Rapp. Gromlands geol. Unders. 1611. 83-86.

C. E. b. Geological Survey of Denmark and Greenlanal. Copenhagen

I. G. W.. Nomesesian Polar Institute, Posthoks 5072 Majorstua, N-0301 Os/e. Noniaty 